\title{
Research on the Construction of Double-track Talent Cultivation Mode of Business English in the Context of Globalization
}

\author{
Ming Fang \\ Hubei University of Science and Technology, Xianning City, Hubei Province, 437005
}

Keywords: globalized context, double-track system of business English, education mode

\begin{abstract}
With the constant development of the society, the difficulty of talent cultivation also raises. The traditional education mode cannot satisfy the demands and development of contemporary education. Meanwhile, the traditional teaching mode cannot cultivate the innovative talents. In addition, under the globalized development background, the requirements of education of business English in terms of professionalism and occupation are also being improved, which also indirectly requires the innovation and development for the talent cultivation mode. Therefore, in order to better improve the talent cultivation quality, this paper analyzes the construction of the double-track talent cultivation mode of business English in the context of globalization.
\end{abstract}

\section{Introduction}

In face of the market environment with the increasing contemporary competition pressure, the students' employment pressure is also being improved; the Business English majors' ability in terms of social competition is also being weakened. The previous professional education mainly focused on basic ability, which cultivated students' oriented business English narration ability. It was not flexible, leading to the non-ideal outcome of talent cultivation. Therefore, to carry out the double-track teaching mode reform in the globalized context is the necessary road for the Business English majors. It emphasizes the students' cultivation of individualized thoughts and the improvement of vocational abilities and allows students to understand and create through self-perception, so as to realize the cultivation objective of the innovation ability.

\section{Construction Value of Double-track Talent Cultivation Mode of Business English}

The reform of the teaching mode must be set according to the cultivation objective in the globalized context. In the reform process, the teaching reform must change the traditional teaching mode. Meanwhile, the excellent part of the traditional teaching mode is preserved and improved, the terrible part is changed or abandoned. Later, adopt the most effective mode on this basis to arouse students' ability and awareness of learning and exploration and realize the cultivation objective of the innovation ability [1]. For the double-track system of business English, the reform of the teaching mode is of great importance. In the current double-system education of Business English, the teaching modes are generally fixed, which cannot realize the cultivation objective of students' innovation ability and meanwhile cannot deeply explore the creative ability of students. Therefore, the reform of the teaching mode seems very necessary. The reform of the teaching mode is not merely done in terms of the teaching methods, but also innovated through multiple approaches such as the thought, objective and task and score evaluation, so as to guarantee the effectiveness of the entire education benefit. 


\section{Status Quo of Talent Cultivation of Business English}

\subsection{Insufficient Teaching Strength}

At present, there are not many talents engaged in business English education in our country. Universities have been expanding the recruitment scale, but the planned economy feature in domestic universities is relatively strong, the scale of teachers does not have obvious increase and the professional education teaching resources of business English are insufficient. Meanwhile, many teachers have disadvantages in terms of professionalism. Most of the education tasks of business English are borne by the English teachers, so that the characteristics of double-track system cannot be highlighted in the actual education. Only specialization can be realized, but professionalism cannot be realized [2].

\subsection{Vague Teaching Ideas}

The education idea is the key issue for the talent cultivation of business English in the context of globalization, but at present, many teachers have certain defects in terms of teaching. In the education of business English, teachers mainly focus on theoretical teaching and adopt the traditional teaching modes such as oral narration, illustration and note, so that students can only master the theoretical knowledge but cannot master the practice ability [3]. Meanwhile, under this teaching mode, teachers' subject cognition in the business field is not clear, making it easily blur students' learning awareness, the employment prospect and development objective. They generally regard the acquisition of certificate as the learning objective, thus leading to the useless value in the practice market.

\section{Cultivation of Double-track System Talent Cultivation Mode of Business English in the Context of Globalization}

\subsection{Innovate the Teaching Thought, Make Clear the Key Points of Education}

The design of the teaching thought is the key and the basic premise in the entire teaching activity. It is the effective combination of teaching theories and teaching practice and is the entirety in the curriculum teaching, which directly determines students' understanding and mastery of knowledge. It is an effective approach to promote the middle school students in the class teaching to turn students' knowledge to the concrete behavior ability. The coordination must be reached among teachers, students and teaching materials, so as to construct a reasonable, systematic and scientific teaching design [4]. The design of the teaching thought must start from teaching materials, summarize the contents in the teaching materials and make clear the teaching objectives that must be reached in each teaching section. Teachers can firstly have a unified understanding of the teaching material outline and teaching materials, promote the teachers not to deviate from the outline orientation and the concrete tasks. Meanwhile, they should conduct the in-depth analysis and discussion of the teaching materials. The purpose of the analysis discussion is not merely to study the teaching materials, but also to analyze the students' demands. Conduct proper extension and expansion of the knowledge points in the teaching materials, expand students' horizons to the fullest and promote students' innovation ability and thought improvement to have the adequate space.

\subsection{Make Clear the Teaching Objectives and Tasks, Highlight the Cultivation Objectives}

The teaching objectives and tasks are the key for teachers to adjust the teaching progress and teaching orientation and meanwhile the key to cultivate students' concrete abilities and awareness. The double-track education reform of business English has relatively big freedom. Meanwhile, the teaching contents may also be extended or reduced out of the actual teaching. But it still has higher reliance for the course class preparations of the purpose, contents, steps and methods. In the actual education, 
teachers need to focus on the characteristics of double-track system and students' actual abilities and habits according to the pre-made educational plan, keep adjusting and controlling the teaching rhythms, so as to guarantee that the ultimate purpose and the teaching tasks of education are smoothly finished. In the teaching process, students need to carry out the exploratory exercise training at the initial stage of teaching. At the beginning of teaching, often carry out the exploratory training and cultivate students' creation awareness through the mode of steps and awareness. Meanwhile, apply it to the basic teaching. The traditional innovation teaching mode emphasizing skills and belittling creation highlights the teaching principles of the skill training and creation. Through the long-term teaching mode reform, promote students' basic knowledge and skill cultivation to be improved, pay attention to students' innovation ability.

\subsection{Introduce and Cultivate the Teaching Strength}

At present, the most objective restricting factor in the talent cultivation of business English in our country is that there is less professional education strength. The cultivation of business English is not the education of English. The professional business cultivation merely takes English as the superficial form and focuses on the major, so as to make it difficult for the business English education in our country to realize double-track system [5]. For this issue, we need to cultivate the talents of this type. First of all, take advantage of the introduction strategies. The introduction objects have two types. The first type is the working staff specially engaged in professional business English or professional education talents in foreign countries. Vigorously explore and introduce the talents. The researches of many foreign countries of business English are mature, so introduction must play the promoting role in the entire education in our country. In addition, the type of talents have worked for a longer time in the education of the business English major, the teaching practice experience of whom is more important and precious compared with the teaching theories of the business English, so its realistic meaning in the teaching is more outstanding. The second type is the talents of the related discipline of the business studies in the English-speaking counties. Meanwhile, they are also the talents that learn the business studies and turn to the business studies. The talents of the business English and the professional training talents of the business English are very rare, showing the condition with price but without market. However, there are many talents engaged in related majors in the English-speaking countries. They have the stronger business qualities. English is the focus in terms of the language, so it can be better transformed to the business English. At present, the popular business English majors in foreign countries mainly include financial trade, business management and business psychology. The main schools and educational resources are distributed in the United States. And the exchange language is English, so the talents are more widespread than the pure business English majors, which keeps in line with the status quo in our country.

\subsection{Construct the Practical Education Base}

The nature of business English still focuses on the English. And the language education focuses on practice and application [6]. English without practice just loses the function. In the process of carrying out the cultivation of business English talents, we need to pay high attention to the education practice and attain the education purpose of flexibly learning and applying. In the education process, we need to pay high attention to the implementation of the practical education of business English. On the one hand, the teaching mode of school-enterprise cooperation can be adopted to set up the practical education base. The internship mode is adopted to cultivate students' practical abilities. The major of business English in our country did not start early, so it obviously falls behind other countries in terms of theoretical research and teaching mode. The innovation of talent cultivation mode in carrying out exchanges and cooperation is still the key project. Therefore, the education organizations need to take the initiative to cooperate with related enterprises or departments, such as the foreign enterprises, so as to realize the cultivation purpose of business English through claiming the internship posts for the 
foreign enterprises. On the other hand, the educational organizations jointly set up the practical bases. Through the joint cooperation of multiple educational organizations, set up a dual-track training base of business English. The form of the base can be enterprise. Through the training base, provide the dual-track cultivation conditions for the school students. In addition, in the creation process of the training base, teachers still need to pay great attention to the cultivation system construction of talents, master the defects existing in the teaching process and keep adjusting and improving according to the actual demands of the market. Teachers can deeply know about the environment status quo of the international business through the in-depth understanding of enterprises, analyze the objective demands of the markets, regard the demand design as the concrete education plan of business English, satisfy the market demands and form the good market environment, so that the students of the business English major can better aster and know about the flow and basic mode of business negotiations.

\subsection{Improve the Evaluation System, Realize the Sustainable Improvement of Abilities}

In the previous dual-track system education of business English, students' scores were evaluated in class according to the completion effect of assignment. Although this evaluation mode is easily realized, yet it has the obvious features of being one-sided and unfair. The score examination of the English major has obvious differences compared with the theoretical courses; the comprehensive and rigid evaluation cannot be realized through merely one assignment. Therefore, improvement needs to be make in terms of the evaluation system. Innovate the dual-track examination mode. The examination objective lies in the professional ability and vocational ability of students. The original evaluation through one assignment is broken and students are examined from multiple perspectives, so as to better show students' comprehensive learning conditions of students,

In terms of the concrete reform modes, students' class learning behaviors need to be firstly evaluated. It is mainly to examine whether students truly devote themselves in the class learning through multiple indexes such as students' thinking and speech conditions, assignment attitude and the completion quality. Meanwhile, the teachers make evaluations. Second, teachers make evaluations from the unit course examinations by referring to the opinions of the teachers and students' attendance conditions. Finally, at the end of the term, conduct comprehensive adjustment according to students' common learning habits and scores, so as to make scores reach the entirety balance and try to highlight the excellent scores of students.

\section{Conclusions}

Above all, the dual-track teaching mode of business English belongs to the long-term and periodical activity. It cannot achieve significant effects in a short period of time. The reform effect of the teaching mode can be highlighted on the basis of a certain period of constant perseverance and innovation. Therefore, in the future education, teachers have to keep innovating and reforming and make innovations and optimization of the courses from the multiple perspectives such as the teaching methods, contents and ideas according to the actual conditions of students and provide foundations for the innovation abilities of students, so as to guarantee the innovative effects and realize the objective of talent cultivation.

\section{References}

[1] Ling Wei. Exploration of the Talent Cultivation Mode of Business English-Review of Research of Talent Cultivation of Business English in Universities [J]. Journal of the Chinese Society of Education, 2017, 19(8):233-234.

[2] Lv Xiaoxuan. Construct Research of Multiplex Reading \& Writing Ability of Business English Majors from the Perspective of Multiple Modals [J]. Journal of Agricultural University of Hebei 
(Agriculture \& Forestry Education), 2017, 19(1):47-51.

[3] Ma Lihong, Zheng Licai. Thinking of Business English Talent Cultivation of School of Continuing School from the Perspective of Adult Education [J]. Education and Vocation, 2015, 24(3):57-58.

[4] Hu Lu. On Multi-mode of College Business English Class Teaching-Review of Business English Teaching Research [J]. Journal of the Chinese Society of Education, 2015, 31(4):133-134.

[5] Li Zhuo. A Brief Analysis of Business English Research from Multiple Perspectives-Review of Business English Research [J]. Theory and Practice of Education, 2017, 14(14):220-221.

[6] Zhao Xiulian. Exploration of Modern English Translation Skills-Review of Translation Course of Business English (Interpreting) [J]. Journal of the Chinese Society of Education, 2017, 23(4):23-24. 